\title{
PENERAPAN MODEL PEMBELAJARAN TAKAR SI JAPRI PADA PEMBELAJARAN EKONOMI DI SMAN 1 TOBOALI
}

\author{
Jasman \\ SMAN 1 Lepar Pongok \\ jasman_2111@yahoo.com
}

\begin{abstract}
Abstrak
Penerapan model pembelajaran Takar Si Japri bertujuan melatih peserta didik untuk lincah menggali informasi, terampil berdiskusi, dan berani berargumen. Sedangkan tujuan akhir pembelajaran ini untuk meningkatkan pengetahuan peserta didik terhadap konsep materi Lembaga Jasa Keuangan. Takar Si Japri merupakan singkatan Tanya, Tukar, Literasi, Jawab, Presentasi. Lima kata tersebut merupakan rangkaian kegiatan pembelajaran yang dilakukan oleh peserta didik ketika mengikuti kegiatan ekonomi di SMAN 1 Toboali. Berdasarkan hasil pembelajaran dapat dilihat bahwa rata-rata nilai pengetahuan dan keterampilan peserta didik kelas X IPS 3 mengalami peningkatan dari siklus 1 ke siklus 2. Rata-rata nilai keterampilan siklus 1 sebesar 75,19 menjadi 79,22. Sedangkan nilai pengetahuan, pada siklus 1 rata-rata 81,31 meningkat pada siklus 2 menjadi 84,31. Berdasarkan hasil analisis data pada bagian sebelumnya dapat ditarik kesimpulan bahwa terdapat perbedaan yang signifikan pada kompetensi keterampilan dan kompetensi pengetahuan peserta didik Kelas X IPS 3 SMAN 1 Toboali pada mata pelajaran ekonomi sebelum penerapan model pembelajaran Takar Si Japri setelah penerapan model pembelajaran Takar Si Japri.
\end{abstract}

Kata Kunci: Takar Si Japri; Uji F; Pengetahuan dan Keterampilan.

\begin{abstract}
The goal of Takar Si Japri recommend the students to agile delving information, skilled in discussion, and bolding in giving argument. The final goal is to increase the the students kognitive in Lembaga Jasa Keuangan. Takar Si Japri is acronym of Tanya (Ask), Tukar (Change), Literasi (Literacy), Jawab (Answer), and Presentasi (Presentation). They are the sequence of learning process in the classroom. The result of learning is significant increasing the mean of cognitive and psychomotor in each step of learning. The conclusion said that there is the significance increasing the cognitive and psikomotoric competence for the students by Takar Si Japri model.
\end{abstract}

Keywords: Takar Si Japri; F Tes; the Cognitive and Psikomotoric Competence. 


\section{Edutainment : Jurnal Ilmu Pendidikan dan Kependidikan}

Volume 7 Nomor 2 Edisi Juli-Desember 2019

\section{PENDAHULUAN}

Kompleksitas tujuan pembelajaran saat ini menjadi tuntutan tersendiri bagi guru di kelas. Sebagai ujung tombak pendidikan, guru harus mampu mewujudkan cita-cita pendidikan yang dikonsep oleh para stakeholder. Guru harus mampu menyusun strategi pembelajaran yang sesuai dengan karakteristik daerah, mata pelajaran, materi, bahkan setiap individu peserta didik.

Strategi pembelajaran konvensional diyakini tidak mampu mencapai target pembelajaran di atas. Pembelajaran yang monoton pun tidak mampu mencapai target pembelajaran yang diharapkan. Karena itu, guru mata pelajaran mesti menerapkan strategi pembelajaran yang bervariatif. Misalnya guru menerapkan pendekatan pembelajaran yang saintifik dengan model pembelajaran yang menarik. Sebagaimana yang dikaji dalam pedoman mata pelajaran di Kurikulum 2013, setiap mata pelajaran dapat dilaksanakan dengan model-model pembelajaran yang ditetapkan.

Seorang guru harus mampu memvariasikan pembelajaran agar lebih menarik. Variasi pembelajaran bisa dilaksanakan dengan menerapkan model pembelajaran, penggunaan media pembelajaran, atau hal-hal lain. Variasi pembelajaran yang terpenting yaitu inovasi pembelajaran.

Pada pembelajaran ini, peneliti melakukan inovasi pembelajaran dengan menggunakan pendekatan santifik dengan model pembelajaran Takar Si Japri. Melalui penerapan Model pembelajaran Takar Si Japri, guru melaksanakan pembelajaran yang menonjolkan kerjasama dan saling membantu sesama anggota kelompok. Model Takar Si Japri juga melatih peserta didik bersikap sportif, karena ada unsur kompetisi antar kelompok diskusi. Artinya, Model Takar Si Japri juga berorientasi pada penguatan pendidikan karakter peserta didik.

Di samping itu, Model Takar Si Japri tidak mengabaikan unsur penanaman pengetahuan dan keterampilan. Dalam model Takar Si Japri peserta didik dilatih untuk lincah menggali informasi, terampil berdiskusi, dan berani berargumen. Unsur ini diyakini berpengaruh terhadap pengetahuan peserta didik terhadap sautu konsep materi pembelajaran.

Model pembelajaran Takar Si Japri mengadopsi model pembelajaran inquiri. model pembelajaran inkuiri yang disusun oleh Richard Suchman dan dirancang untuk mengembangkan penalaran didasarkan pada tatacara penelitian ilmiah. Model pembelajaran kelompok yang disusun oleh Hebert Thelen yang dirancang untuk melatih partisipasi dan 
Edutainment : Jurnal Ilmu Pendidikan dan Kependidikan

Volume 7 Nomor 2 Edisi Juli-Desember 2019

kerjasama dalam kelompok didasarkan pada teori John Dewey.

Beberapa penelitian menggunakan model pembelajaran serupa juga telah dilakukan. Erlina (2019) dengan model pembelajaran PBL tipe SSCS (Search, Solve, Create, and Share) berhasil meningkatkan hasil belajar peserta didik pada materi akuntansi.

Penelitian yang dilaksanakan Handayani (2018) di SDN 3 Pangkalpinang dengan model inkuiri berhasil meningkatkan pemahaman konsep materi pelajaran peserta didik. Hal ini terjadi, karena Pembelajaran IPA sebaiknya dilaksanakan secara inkuiri ilmiah (scientific inquiry) untuk menumbuhkan kemampuan berpikir, bekerja dan bersikap ilmiah serta mengkomunikasikannya sebagai aspek penting kecakapan hidup.

Atas dasar di atas, peneliti mengadakan pembelajaran dengan model pembelajaran Takar Si Japri di Kelas X SMA Negeri 1 Toboali pada mata pelajaran Ekonomi. Penelitian ini bertujuan untuk meminimalisasi kelemahan pembelajaran yang sering peneliti temui di kelas. Di Kelas X IPS 3, sebagian besar peserta didik menjadi catatan guru pada saat pembelajaran berlangsung. Mereka kurang peduli dengan kegiatan diskusi yang berlangsung. Bahkan ada yang tertidur di kelas saat belajar. Di Kelas X IPS 3, secara dominan peserta didik terlalu fokus dengan kesibukan masing-masng daripada ikut kegiatan tanya jawab.

Hal ini bisa saja disebabkan karena guru kurang variatif dalam melaksanakan pembelajaran di kelas. Secara rutin, guru selalu melaksanakan pembelajaran dengan langkah-langkah yang sama. Hanya saja, guru pernah melakukan variasi pembagian kelompok dengan menggunakan permen. Tetapi pembelajaran tetap saja berjalan kurang menarik. Oleh karena itu, melalui penelitian ini guru mencoba apakah model pembelajaran Takar Si Japri ini bisa membantu guru meminimalisir kelemahankelemahan pembelajaran tersebut.

PTK ini dilaksanakan dengan tujuan untuk mengetahui tentang: Untuk mengetahui signifikansi peningkatan kompetensi keterampilan (Kompetensi Inti/KI 4) peserta didik Kelas X IPS 3 SMAN 1 Toboali pada mata pelajaran ekonomi dengan model pembelajaran Takar Si Japri, untuk mengetahui signifikansi peningkatan kompetensi pengetahuan (KI 3) peserta didik Kelas X IPS 3 SMAN 1 Toboali pada mata pelajaran ekonomi dengan model pembelajaran Takar Si Japri.

\section{METODE PENELITIAN}

PTK ini dilakukan di kelas X IPS 3 SMA Negeri 1 Toboali pada mata pelajaran ekonomi. Jumlah siswa di kelas 
tersebut sebanyak 36 orang. Siswa di kelas $X$ IPS 3 ini memiliki karakteristik yang berbeda dengan kelas yang lain. Siswa kelas ini memiliki kemampuan akademik yang relatif lebih rendah dari kelas lainnya.

Adapun jadwal pelaksanaan perbaikan pembelajaran disesuaikan dengan jadwal pelajaran sehari-hari di kelas tersebut. Dalam satu minggu, mata pelajaran ekonomi mempunyai alokasi waktu 3 jam pelajaran. Jadi, setiap setiap pertemuan akan dilaksanakan selama 3 jam pelajaran.

Pelaksanaan penelitian ini dilaksanakan selama kurang lebih 2 bulan, yakni bulan Januari dan Februari 2019. Kegiatan ini dimulai dengan kegiatan penyusunan proposal penelitian, penyusunan perangkat penilaian, pelaksanaan, dan pelaporan.

Sebagaimana lazimnya penelitian tindakan, penelitian ini bertujuan melakukan perbaikan pembelajaran pada mata pelajaran ekonomi di Kelas X IPS 3 Tahun Pelajaran 2018/2019. Perbaikan pembelajaran dilaksanakan selama dua siklus perbaikan pembelajaran. Setiap siklus terdiri dari empat kegiatan, yakni perencanaan, pelaksanaan, observasi, dan refleksi.

Secara global, pembelajaran model pembelajaran Takar Si Japri dilaksanakan dengan prosedur sebagai berikut: Tahapan Stimulus berupa video, gambar, atau wacana; Setiap kelompok menyusun soal (pertanyaan) berdasarkan hasil pengamatan stimulus; Acak Soal untuk dijawab oleh kelompok lainnya; Literasi, yakni kegiatan diskusi untuk membahas pertanyaan yang diperoleh dari hasil pengacakan; Acak soal dan penyelesaiannya tahap selanjutnnya; Presentasi kelompok; Penilaian individu untuk diakumulasikan pada setiap kelompok.

\section{Batasan Penelitian}

Batasan penelitian yaitu standar yang ditentukan untuk menentukan keberhasilan PTK ini. Oleh karena itu, peneliti menggunakan sebuah indikator. Indikator keberhasilan perbaikan pembelajaran pada PTK ini yaitu terjadinya peningkatan pada: Nilai tes hasil belajar peserta didik klasikal minimal 80; Tingkat Ketuntasan belajar klasikal untuk kompetensi pengetahuan sebesar $80 \%$ siswa tuntas; Aktivitas pembelajaran untuk mengukur kompetensi keterampilan peserta didik minimal $75 \%$.

\section{Teknis Analisis Data dan Pengujian Hipotesa}

Untuk mendapatkan gambaran tentang data yang diteliti perlu diadakan sebuah pengolahan dan analisis data yang sesuai dengan metode penelitian. Tujuannya untuk menilai apakah ada perubahan yang signifikan antara hasil pembelajaran setiap siklus. Oleh karena itu, pengujian yang 
Edutainment : Jurnal Ilmu Pendidikan dan Kependidikan

Volume 7 Nomor 2 Edisi Juli-Desember 2019

digunakan pada penelitian ini yaitu Uji Anova atau dengan Uji F. Uji F digunakan untuk menguji hipotesis komparatif dua sampel secara serentak.

Untuk menguji hipotesa digunakan teknik sebagai berikut (Sudaryono, 2014:202; Sugiyono, 2014:151; Creswell, 2016:220): Paired samples statistic untuk menjelaskan analisis data secara deskriptif; Homogeneity of Varian untuk mengukur homogenitas data yang digunakan. Dalam hal ini, peneliti menerapkan bahwa syarat homogenitas ditentukan dengan taraf signifikansi 0,05. Jika hasil uji menunjukkan nilai Signifikansi lebih dari 0,05; ANOVA untuk menguji hasil $\mathrm{F}$ tabel dengan F Hitung; Penarikan kesimpulan melalui pengujian hipotesis.

\section{HASIL DAN PEMBAHASAN}

\section{Analisis Homogenitas Data}

Homogeneity of Varian untuk mengukur homogenitas data yang digunakan. Uji ini untuk melihat apakah data yang diperoleh merupakan data yang homogen atau tidak. Dalam hal ini, peneliti menerapkan bahwa syarat homogenitas ditentukan dengan taraf signifikansi 0,05. Jika hasil uji menunjukkan nilai Signifikansi lebih dari 0,05 maka data tersebut dinyatakan sebagai data yang homogen.
Tabel 1. Homogeneity of Varian

Pengetahuan

\begin{tabular}{|c|c|c|c|}
\hline $\begin{array}{c}\text { Levene } \\
\text { Statistic }\end{array}$ & df1 & df2 & Sig. \\
\hline .023 & 1 & 70 & .879 \\
\hline
\end{tabular}

Tabel 1 menunjukkan bahwa pada uji homogenitas pengetahuan, diperoleh nilai signifikansi sebesar $0,879 . \quad$ Nilai signifikansi lebih dari 0,05 . Dengan demikian, data tersebut disimpulkan bersifat homogen.

Tabel 2. Homogeneity of Varian Keterampilan

\begin{tabular}{|c|c|c|c|}
\hline $\begin{array}{c}\text { Levene } \\
\text { Statistic }\end{array}$ & df1 & df2 & Sig. \\
\hline 10.089 & 1 & 70 & .002 \\
\hline
\end{tabular}

Tabel 2 menunjukkan bahwa pada uji homogenitas nilai kompetensi pengetahuan, diperoleh nilai signifikansi sebesar 0,02. Nilai signifikansi kurang dari 0,05. Dengan demikian, data tersebut disimpulkan bersifat tidak homogen.

\section{Analisis Deskriptif Hasil Pembelajaran}

Berdasarkan hasil pembelajaran siklus 1 dan siklus 2, baik nilai kompetensi pengetahuan dan kompetensi keterampilan, maka peneliti melakukan beberapa analisis terhadap data tersebut dengan menggunakan SPSS 16. Analisis pertama yang dilakukan yaitu analisis deskriptif. 
Edutainment : Jurnal Ilmu Pendidikan dan Kependidikan

Volume 7 Nomor 2 Edisi Juli-Desember 2019

Berdasarkan hasil analisis SPSS sebagai berikut:

Tabel 3. Analisis Deskriptif Nilai

Kompetensi Pengetahuan

\begin{tabular}{|c|c|c|c|c|}
\hline & Mean & $\mathrm{N}$ & \begin{tabular}{|c|} 
Std. \\
Deviatio \\
$\mathrm{n}$
\end{tabular} & $\begin{array}{l}\text { Std. } \\
\text { Error } \\
\text { Mean }\end{array}$ \\
\hline 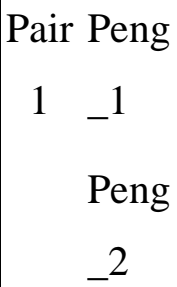 & $\begin{array}{l}81.31 \\
84.31\end{array} \mid$ & $\begin{array}{l}36 \\
36\end{array}$ & $\begin{array}{l}6.136 \\
5.994\end{array}$ & $\begin{array}{r}1.023 \\
.999\end{array}$ \\
\hline
\end{tabular}

Samples Statistics diperoleh hasil bahwa pada kegiatan pembelajaran pada siklus 1 rata-rata nilai harian dari 36 peserta didik 81,31 dengan standar deviasi 6,136 dan standar kesalahan rata-rata 1,023. Sedangkan pada kegiatan pembelajaran siklus 2 rata-rata nilai harian sebesar 84,31 dengan standar deviasi sebesar 5,994 dan standar kesalahan rata-rata 0,999 .

Tabel 4. Analisis Deskriptif Nilai

Kompetensi Keterampilan

\begin{tabular}{|l|l|l|l|l|l|l|}
\hline $\begin{array}{l}\text { nil } \\
\text { ai }\end{array}$ & & & & & & \\
\cline { 1 - 5 } & $\mathrm{N}$ & $\begin{array}{l}\text { Me } \\
\text { an }\end{array}$ & $\begin{array}{l}\text { Std. } \\
\text { Devia } \\
\text { tion }\end{array}$ & $\begin{array}{l}\text { St } \\
\text { d. } \\
\text { Err } \\
\text { or }\end{array}$ & $\begin{array}{l}\text { Mini } \\
\text { mum }\end{array}$ & $\begin{array}{l}\text { Maxi } \\
\text { mum }\end{array}$ \\
\hline 1 & 3 & $\begin{array}{l}75 . \\
19\end{array}$ & 4.628 & $\begin{array}{l}.77 \\
1\end{array}$ & 65 & 83 \\
\hline 2 & 3 & 79. & 3.252 & .54 & 70 & 90 \\
\hline
\end{tabular}

\begin{tabular}{|l|l|l|l|l|l|l|}
\hline & 6 & 22 & & 2 & & \\
\hline To & 7 & 77. & 4.459 & .52 & 65 & 90 \\
tal & 2 & 21 & & 6 & & \\
\hline
\end{tabular}

Keterangan: $\quad \mathrm{X} 1=$ Siklus 1

$\mathrm{X} 2$ = Siklus 2

Tabel 4 di atas tentang Paired Samples Statistics diperoleh hasil bahwa pada kegiatan pembelajaran Siklus 1 ratarata nilai kompetensi keterampilan 36 peserta didik sebesar 75,19 dengan standar deviasi 4,628 dan standar kesalahan ratarata 0,771 . Sedangkan pada kegiatan pembelajaran siklus 2 rata-rata kompetensi keterampilan sebesar 79,22 dengan standar deviasi sebesar 3,252 dan standar kesalahan rata-rata 0,542 .

\section{Uji Hipotesis dengan Uji F}

\section{(ANOVA)}

Untuk menguji hipotesis dengan Uji $\mathrm{F}$ perlu ditetapkan ketentuan kriteria penerimaan hipotesis terlebih dahulu. Sesuai dengan ketentuan pada bagian sebelumnya telah dijelaskan bahwa jika nilai probability 0,05 lebih kecil dari probability Sig atau 0,05 < Sig, dan/atau F hitung $<\mathrm{F}_{\text {tabel }}$, maka $\mathrm{H}_{0}$ diterima dan $\mathrm{H}_{\mathrm{a}}$ ditolak. Jika nilai probability 0,05 lebih besar atau sama dengan probability Sig atau $0,05 \geq \operatorname{Sig}$, dan/atau $F$ hitung $>F_{\text {tabel, }}$ maka $\mathrm{H}_{0}$ ditolak dan $\mathrm{H}_{\mathrm{a}}$ diterima.

Berikut ini hasil analisis data menggunakan SPSS 16. 
Edutainment : Jurnal Ilmu Pendidikan dan Kependidikan

Volume 7 Nomor 2 Edisi Juli-Desember 2019

Tabel 5. Uji F Nilai Kompetensi

Pengetahuan

\begin{tabular}{|l|l|l|l|l|l|}
\hline & $\begin{array}{l}\text { Sum of } \\
\text { Square }\end{array}$ & & Mean & & \\
s & df & Square & F & Sig. \\
\hline Between & 162.00 & 1 & 162.00 & 4.40 & .039 \\
Groups & 0 & 1 & 0 & 3 & \\
Within & 2575.2 & 70 & 36.790 & & \\
Groups & 78 & & & & \\
Total & 2737.2 & 71 & & & \\
\hline
\end{tabular}

Pada tabel ANOVA nilai kompetensi pengetahuan yang didapatkan dari hasil ulangan harian diperoleh sum of square sebesar 162,000. Nilai F hitung pada data tersebut 4,403 dengan derajat kebebasan (n - 1) yaitu 70 pada taraf kesalahan 5\% atau kepercayaan 95\%. Pada pengujian signifikansi dua ekor diperoleh nilai signifikansi sebesar 0,039 .

Pengujian hipotesis dilakukan terhadap nilai $\mathrm{F}$ tabel pada $\mathrm{dk} 70$ dengan derajat kesalahan $5 \%$ sebesar 3,980 . Sedangkan nilai $\mathrm{F}$ hitung pada tabel yaitu 4,403. Artinya diperoleh nilai $\mathrm{F}$ hitung $>\mathrm{F}$ tabel atau 4,403 > 3,980. Nilai signifikansi 0,039, artinya probabilitas > signifikansi atau $0,050>0,0395$. Maka dapat ditarik kesimpulan bahwa Ho ditolak dan $\mathrm{Ha}$ diterima. Artinya terdapat perbedaan signifikan antara nilai kompetensi pengetahuan peserta didik pada siklus 1 dan siklus 2 setelah dilakukan perbaikan pembelajaran pada model Takar Si Japri.

Tabel 6. Uji F Nilai Keterampilan

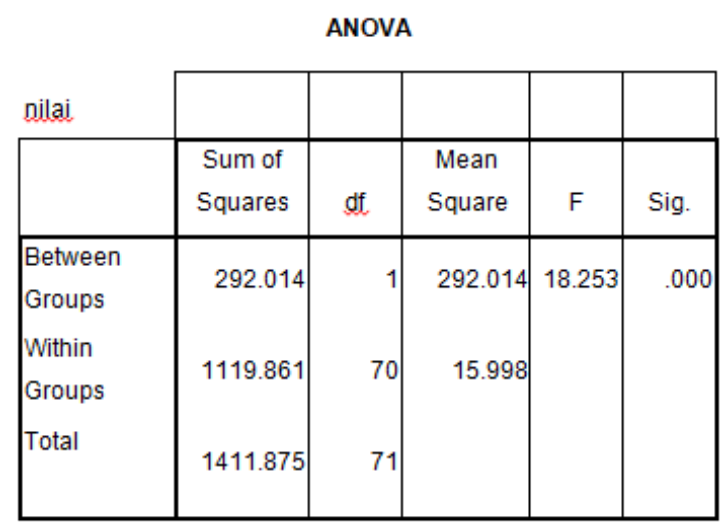

Pada tabel Paired Samples Test nilai sum of square 292,014. Nilai F hitung diperoleh sebsar 18,253 dengan derajat kebebasan $(n-1)$ yaitu 70 pada taraf kesalahan 5\% atau kepercayaan 95\%. Pada pengujian signifikansi dua ekor diperoleh nilai signifikansi sebesar 0,000 .

Pengujian hipotesis dilakukan terhadap nilai $\mathrm{F}$ hitung pada $\mathrm{dk} 70$ dengan derajat kesalahan 5\% sebesar 18,253. Sedangkan nilai $\mathrm{F}$ tabel yaitu 3,980. Artinya nilai $\mathrm{F}$ hitung $<\mathrm{F}$ tabel atau $18,253<3,980$. Nilai signifikansi 0,000 , artinya probabilitas < signifikansi atau $0,050<0,000$. Maka dapat ditarik kesimpulan bahwa Ha diterima dan Ho ditolak. Artinya terdapat perbedaan signifikan antara nilai kompetensi keterampilan peserta didik pada siklus 1 dan siklus 2 setelah dilakukan perbaikan pada model pembelajaran Takar Si Japri. 
Edutainment : Jurnal Ilmu Pendidikan dan Kependidikan

Volume 7 Nomor 2 Edisi Juli-Desember 2019

\section{Pembahasan}

Dari temuan data dan analisis di atas dapat dibuat ringkasan sebagai berikut:

Tabel 7. Hasil Analisis

\begin{tabular}{|c|c|c|}
\hline No & Aspek & Hasil \\
\hline 1 & $\begin{array}{l}\text { Rata-rata nilai } \\
\text { kompetensi } \\
\text { Pengetahuan }\end{array}$ & Meningkat \\
\hline 2 & $\begin{array}{l}\text { Rata-rata nilai } \\
\text { kompetensi } \\
\text { Keterampilan }\end{array}$ & Meningkat \\
\hline 3 & $\begin{array}{l}\text { Homogenitas nilai } \\
\text { kompetensi } \\
\text { pengetahuan }\end{array}$ & Homogen \\
\hline 4 & $\begin{array}{l}\text { Homogenitas nilai } \\
\text { kompetensi } \\
\text { keterampilan }\end{array}$ & $\begin{array}{l}\text { Tidak } \\
\text { Homogen }\end{array}$ \\
\hline 5 & $\begin{array}{l}\text { Uji } \quad \mathrm{T} \text { nilai } \\
\text { kompetensi } \\
\text { pengetahuan }\end{array}$ & $\begin{array}{l}\text { Terdapat } \\
\text { perbedaan }\end{array}$ \\
\hline 6 & $\begin{array}{l}\text { Uji } \quad \mathrm{T} \text { nilai } \\
\text { kompetensi } \\
\text { keterampilan }\end{array}$ & $\begin{array}{l}\text { Terdapat } \\
\text { perbedaan }\end{array}$ \\
\hline
\end{tabular}

Berdasarkan tabel hasil analisis di atas dapat dilihat bahwa rata-rata nilai kompetensi pengetahuan dan kompetensi keterampilan peserta didik kelas X IPS 3 mengalami peningkatan dari siklus $1 \mathrm{ke}$ siklus 2. Rata-rata nilai kompetensi keterampilan siklus 1 sebesar 75,19 menjadi 79,22. Sedangkan nilai kompetensi pengetahuan, pada siklus 1 rata-rata 81,31 meningkat pada siklus 2 menjadi 84,31.

Peningkatan kompetensi keterampilan peserta didik diindikasikan pada beberapa kegiatan pembelajaran. Peserta didik menunjukkan sikap aktif dalam kegiatan pengamatan terhadap stimulus. Setelah kegiatan stimulus selesai, peserta didik diarahkan menyusun pertanyaan untuk diberikan kepada kelompok lain. Kegiatan menjawab pertanyaan acak inilah yang menyebabkan nilai keterampilan meningkat.

Pada kegiatan ini, peserta didik berusaha memecahkan masalah yang diperoleh dengan membaca literatur dari berbagai sumber, baik buku pegangan, buku penunjang, maupun dari internet. Sebagai bentuk laporan, setiap kelompok menuliskan hasil diskusi dalam sebuah laporan yang akan dipresentasikan di depan kelas.

Peningkatan keaktivan peserta didik pada setiap siklus berpengaruh terhadap peningkatan nilai kompetensi pengetahuan. Artinya, ada hubungan positif antara tingkat keaktivan terhadap penguasaan materi oleh peserta didik. Bahkan, penilaian yang dilakukan pada akhir pembelajaran sudah sampai soal pada level C4 atau level soal HOTS. Dengan kata lain, dengan menerapkan pembelajaran model Takar Si Japri ini peserta didik telah mampu melakukan tahap analisis 


\section{Edutainment : Jurnal Ilmu Pendidikan dan Kependidikan}

Volume 7 Nomor 2 Edisi Juli-Desember 2019

persoalan yang berkaitan dengan materi pelajaran.

Peningkatan nilai kompetensi pengetahuan terjadi karena pada siklus 2 dilaksanakan beberapa perubahan alur pembelajaran dan perubahan bentuk penilaian tertulis menggunakan soal uraian berbasis HOTS. Pada kegiatan pembelajaran siklus 1 , penilaian tertulis dilakukan menggunakan soal uraian berbasis LOTS. Tetapi, bentuk soal pada penilaian ini tidak terhadap nilai ulangan harian peserta didik.

Perubahan positif hasil pembelajaran ini sejalan dengan maksud pelaksanaan model Takar Si Japri. Model Takar Si Japri tidak mengabaikan unsur penanaman kompetensi pengetahuan dan kompetensi keterampilan. Dalam model Takar Si Japri peserta didik dilatih untuk lincah menggali informasi, terampil berdiskusi, dan berani berargumen. Unsur ini diyakini berpengaruh terhadap pengetahuan peserta didik terhadap suatu konsep materi pembelajaran. Model pembelajaran Takar Si Japri ini akan diterapkan untuk mengukur hasil belajar peserta didik pada aspek sikap sosial, keterampilan, dan pengetahuan.

Pada siklus 2, ada beberapa perbaikan yang dilakukan: Pembagian kelompok tidak dilakukan secara acak, melainkan diatur menurut tingkat intake peserta didik; Pemberian stimulus dilakukan dengan menggunakan video dan gambar yang sifatnya kontekstual; Pelaksanaan tukar pertanyaan dilakukan secara acak dalam beberapa kali ulang; Peserta didik secara berkelompok merumuskan kesimpulan dari masalah pokok yang didiskusikan dan mengomunikasikan di depan kelas; Pada kegiatan penilaian hasil, instrumen penilaian menggunakan soal berbasis HOTS.

Model pembelajaran Takar Si Japri mengadopsi model pembelajara inquiri. Model pembelajaran inkuiri yang disusun oleh Richard Suchman dan dirancang untuk mengembangkan penalaran didasarkan pada tata cara penelitian ilmiah. Model pembelajaran kelompok yang disusun oleh Hebert Thelen yang dirancang untuk melatih partisipasi dan kerja sama dalam kelompok didasarkan pada teori John Dewey.

Merujuk pada indikator keberhasilan penelitian, peneliti memandang bahwa PTK yang dilakukan ini sudah melampaui batas minimal yang dipersyaratkan di awal. Nilai rata-rata kompetensi pengetahuan diperoleh 84,31 dan nilai kompetensi keterampilan diperoleh 79,22. Kedua perolehan tersebut lebih dari standar minimal sebesar 80,00 pada kompetensi pengetahuan dan 75,00 pada kompetensi keterampilan. Sehingga, penelitian ini dibatasi pada siklus 2 . 
Edutainment : Jurnal Ilmu Pendidikan dan Kependidikan

Volume 7 Nomor 2 Edisi Juli-Desember 2019

Dengan kata lain, PTK ini tidak dilanjutkan ke siklus 3 .

Hasil penelitian ini secara global sama dengan hasil penelitian yang dilakukan Erlina (2019) di SMKN 1 Sungailiat. Dengan menerapkan model PBL dengan pendekatan SSCS, penelitian dapat meningkatkan hasil pembelajaran peserta didik.

Peningkatan disebabkan adanya perbaikan pembelajaran setiap siklus. Pendekatan SSCS yang dilakukan sejalan dengan model pembelajaran Takar Si Japri. Ada tahap-tahap pembelajaran yang sama seperti; 1) search, yakni proses pengumpulan informasi dari berbagai sumber, 2) tahap penyusunan soal sebagai stimulus dan bahan diskusi kelompok untuk memecahkan masalah, 3) tahap kreativitas peserta didik ketika diberikan tugas pemecahan masalah, 4) komunikasi antar kelompok dengan wadah presentasi kelompok.

\section{SIMPULAN DAN SARAN}

Berdasarkan hasil analisis data pada bagian sebelumnya dapat ditarik kesimpulan bahwa: Terdapat perbedaan yang signifikan pada kompetensi keterampilan peserta didik Kelas X IPS 3 SMAN 1 Toboali pada mata pelajaran ekonomi pada siklus 1 dan siklus 2; Terdapat perbedaan signifikan pada kompetensi pengetahuan peserta didik Kelas X IPS 3 SMAN 1 Toboali pada mata pelajaran ekonomi pada siklus 1 dan siklus 2.

Dari hasil PTK ini, ada beberapa saran yang diberikan: Penerapan model pembelajaran Takar Si Japri boleh diterapkan pada kegiatan pembelajaran lainnya dengan melakukan beberapa perbaikan dan penyesuian yang dperlukan; Hendaknya bagi penelitian lainnya memperhatikan level soal pada kegiatan penilaian pengetahuan supaya tingkat pengetahuan bisa diukur lebih valid; Peneliti ingin menerapkan model pembelajaran Takar Si Japri pada subjek atau kelas lainnya sebagai bentuk pengembangan model pembelajaran.

\section{DAFTAR PUSTAKA}

Creswell, John W. (2016). Research Design. Diterjemahkan Ahmad Fawaid dan Rianayati Kusmini Pancasari. Yogyakarta: Pustaka Pelajar.

Erlina, Nina. 2019. Penerapan Pembelajaran Problem Based Learning Tipe SSCS untuk Meningkatkan Hasil Belajar Peserta Didik. Jurnal Edutaiment Vol. 7 No. 1, Hal. $94-108$.

Handayani, Tut Wuri. 2018. Peningkatan Pemahaman Konsep IPA Menggunakan Model Pembelajaran Inkuiri Terbimbing di SD. Jurnal Edutaiment Vol. 6 No. 2 Hal. $130-$ 153. 
Edutainment : Jurnal Ilmu Pendidikan dan Kependidikan

Volume 7 Nomor 2 Edisi Juli-Desember 2019

Sudaryono. (2014). Aplikasi Statistika

untuk Penelitian. Jakarta: Lentera

Ilmu.

Sugiyono. (2014). Metode Penelitian

Kuantitatif Kualitatif dan $R \& D$.

Bandung: Alfabeta. 